\title{
DEVELOPMENT OF CINNAMON
}

\section{FLAVOURED INSTANT PORRIDGE}

\section{POWDER USING AMYLASE TREATED}

\author{
KITHUL FLOUR (Caryota urens)
}

\author{
BY \\ Kuhanneya Kugamohan
}

Thesis submitted to the University of Sri Jayewardanapura for the award of Degree of Master of Science in Food Science and Technology in 2015 


\section{DECLARATION}

The work described in this thesis was carried out by me under the supervision of Dr.R.A.U.J.Marapana, Senior Lecturer, Department of Food Science and Technology, Faculty of Applied Sciences, University of Sri Jayewardenepura and Dr. P. Ranasinghe, Senior Deputy Director, Herbal Technology Section, Industrial Technology Institute and a report on this has not been submitted in whole or in part to any University or any other Institution for another Degree or Diploma.

$8 / 12 / 2015$

Date

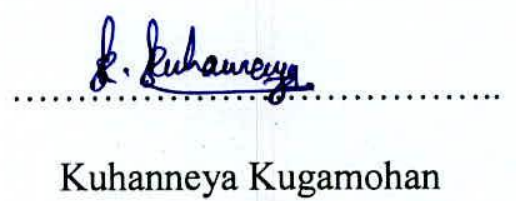

Kuhanneya Kugamohan 
We certify that the above statement made by the candidate is true and that this thesis is suitable for submission to the University for the purpose of evaluation.

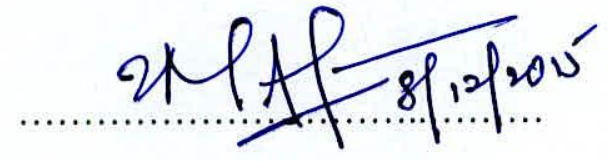

Dr. R.A.U.J. Marapana

Senior Lecturer,

Department of Food Science and

Technology,

Faculty of Applied Sciences,

University of Sri Jayewardenepura,

Gangodawila,

Nugegoda,

Sri Lanka.

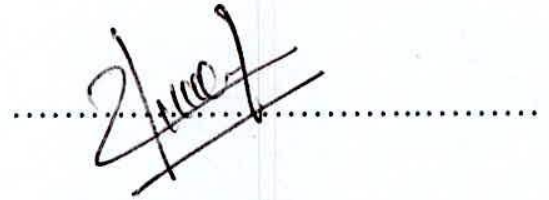

Dr. P. Ranasinghe,

Senior Deputy Director,

Herbal Technology Section,

Industrial Technology Institute,

Bauddhaloka Mawatha,

Colombo - 7,

Sri Lanka. 


\section{DEDICATION}

Affectionately dedicated to

my Parents and

my loving Husband 


\section{TABLE OF CONTENTS}

TABLE OF CONTENTS .........................................................................................

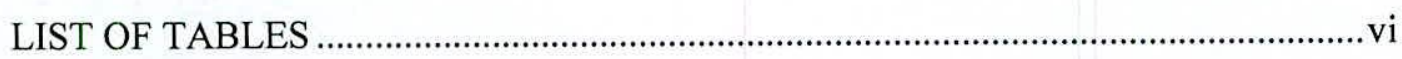

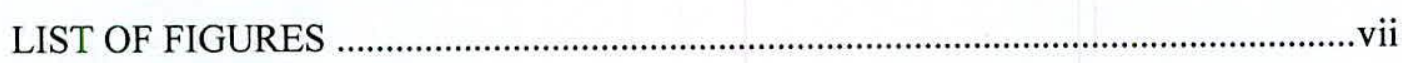

ACKNOWLEDGEMENT ….....................................................................................ii

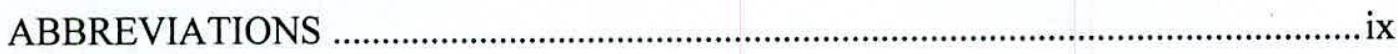

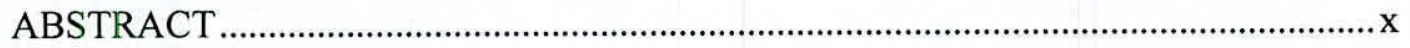

Chapter 1:

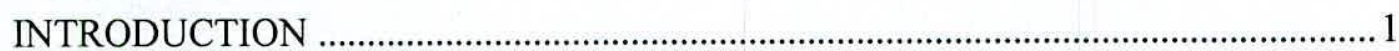

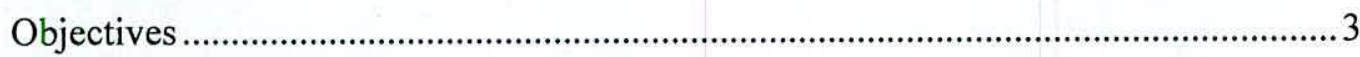

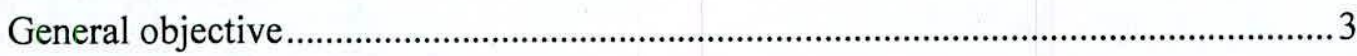

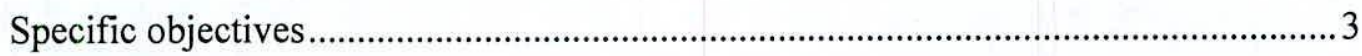

Chapter 2:

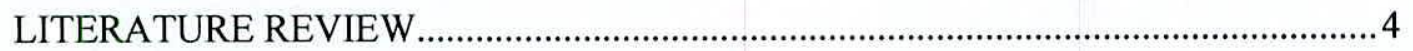

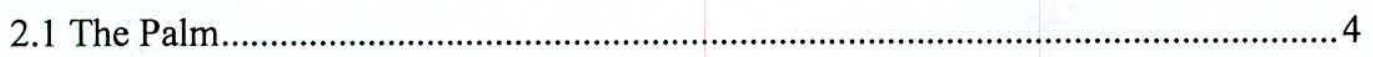

2.2 Kithul (Caryota urens) flour Extraction ……….....................................................

2.3 Identification and Chemical Parameters..........................................................

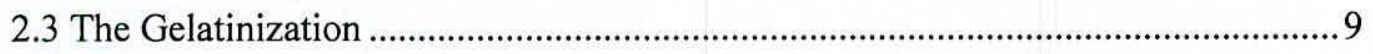


2.4 Gelatinization temperature

2.5 Gelation Studies

2.6 Factors affecting starch analysis 12

2.6.1 The use of enzyme in starch hydrolysis .14

2.6.2 Starch 15

2.6.3 Application of Starch ..... .19

2.6.4 Percentage of water soluble materials present in starch 20

2.7 Alpha Amylase 20

2.8 Cinnamon (Cinnamomum zeylanicum) 21

2.8.1 Cinnamon as an antidiabetic agent .22

2.9 Identification of reducing sugar in Kithul Flour .22

2.9.1 Maltose .23

2.9.2 The importance of DNS assay in determining reducing sugar content .24

2.9.3 Determination of Maltose by DNS method (Miller,1959). .25

2.9.4 Spectrophotometry 26

2.10 Antioxidant Property

2.10.1 Total Polyphenolic Content (TPC) Assay Principle .28

2.10.2 Oxygen Radical Absorbance Capacity (ORAC) of Selected Foods .29 
2.10.3 Ferric Reducing Antioxidant Power (FRAP) Assay......

Chapter 3:

MATERIAL AND METHODS 31

Location .31

3.1 Formulation and development of Instant Kithul porridge powder 31

3.1.1 Establishing an analytical technique to quantify the production of Maltose due to hydrolysis by the Kithul (Caryota urens) flour sample 31

3.2 Gelation Studies 34

3.3 Cinnamon water extraction method. .35

3.3.1 Quantification of cinnamon extract .35

3.4 Sensory Evaluation $1 \& 2$

3.5 Quantification of maltose present in the digested Kithul starch slurry by DNS method.

3.6 Determination of total polyphenolic Content (TPC) and Antioxidant content in the original commercially available kithul flour and final developed cinnamon flavoured kithul porridge powder. 39

3.6.1 Determination of total polyphenolic content (Singleton et al., 1999) 39

3.6.2 Determinig the total antioxidant content by Oxygen Radical Absorbance Capacity Assay (ORAC) (Ou et al., 2001). 40 
3.6.3 Determining the Total Antioxidant content by Ferric Reducing Antioxidant Power (FRAP) Assay (Benzie and Szeto, 1999) 41

3.7 Proximate analysis of the Commercial flour and final product. .43

3.7.1 Determination of the moisture content 43

3.7.2 Determination of crude fat content 45

3.7.3 Determination of the protein content 46

3.7.4 Determination of the Ash content (AOAC 923.03) 49

3.7.5 Determination of crude fiber content (AOAC 920.86). .50

3.7.6 Determination of Total carbohydrate 52

3.8 Determination of Maltose by HPLC method 52

Chapter 4:

RESULTS AND DISCUSSION 53

4.1 Determination of Maltose content in the product by plotting curves 53

4.1.1 Developing Standard Maltose curve 53

4.1.2 Determining Texture and the Maltose content in the product .53

4.2 Gelation study of the digested four samples .54

4.3 Cinnamon water Extraction and quantification of dry matter 55

4.4 Sensory Analysis of Instant Kithul Porridge powder..... 55 
4.4.1 Results of best maltose concentration and gelatinization property for the product. (sensory 1) .55

4.4.2 Results of Sensory Evaluation 2 60

4.5 Quantification of Maltose content in the sample selected from the sensory evaluation. 63

4.6 Results of Total Polyphenolic Content and Total Antioxidant content of commercially available flour and developed product .64

4.7 Results of Proximate Analysis of the final product 65

4.8 Results of Maltose content. 67

4.8.1 HPLC results for Standard (Maltose) 67

Chapter 5:

CONCLUSIONS .70

Chapter 6:

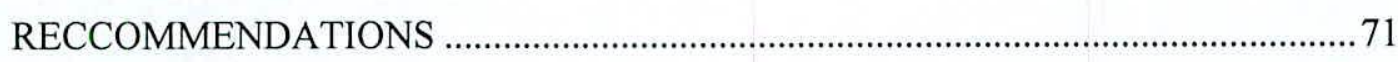

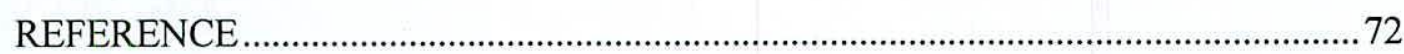

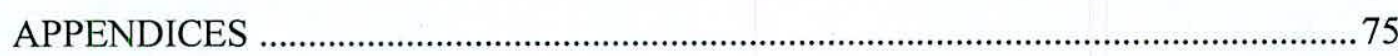




\section{LIST OF TABLES}

Table 2.1 Identification and Chemical composition test of Kithul flour (Wijesinghe et al., 2015) 6

Table 2.2 Variations on Amylose, Amylopectin and total starch of native Kithul flour (Wijesinghe et al., 2015). 8

Table 2.3 Gelation properties of Kithul flour (Wijesinghe et al., 2015) 11

Table 3.1 Ratios of ingredients for different samples .34

Table 3.2 Formula for texture and sweetness analysis for sensory evaluation no: 1 ......37

Table 3.3 Formula for final product analysis for sensory evaluation no: 2 37

Table 4.1 Concentration of Maltose for different hydrolysis ratios 54

Table 4.2 Ratio of hydrolyzed samples for gelation study .54

Table 4.3 Ratios of Kithul flour: Amylase for sensory evaluation 1 .55

Table 4.4 Result of sensory evaluation 1 .58

Table 4.5 Result of Sensory evaluation 2 62

Table 4.6 Total polyphenolic content and antioxidant content in commercial flour and product developed. .64

Table 4.7 Results of Proximate Analysis of the product. .65

Table 4.8 Amount of maltose in commercial flour and product developed. .69 


\section{LIST OF FIGURES}

Figure 2.1 The use of enzymes in processing starch.................................................. 18

Figure 3.1 Process flow diagram (Instant kithul porridge powder) ................................38

Figure 4.1 Evaluation of texture of three porridge samples $(203,411,731) \ldots \ldots \ldots \ldots \ldots . . .57$

Figure 4.2 Evaluation of sweetness of three porridge samples $(203,411,731) \ldots \ldots \ldots \ldots . .57$

Figure 4.3 Evaluation of overall acceptability of three porridge samples $(203,411,731)$

.58

Figure 4.4 Evaluation of spice flavor of the porridge samples $(781,701,723) \ldots \ldots \ldots \ldots . . .60$

Figure 4.5 Evaluation of appearance of the porridge samples $(781,701,723)$.............61

Figure 4.6 Evaluation of overall acceptability of the porridge samples $(781,701,723) 61$

Figure 4.7 Evaluation of odour of the porridge samples $(781,701,723) \ldots \ldots \ldots \ldots \ldots \ldots \ldots . . .62$

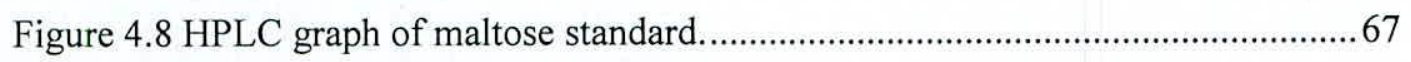

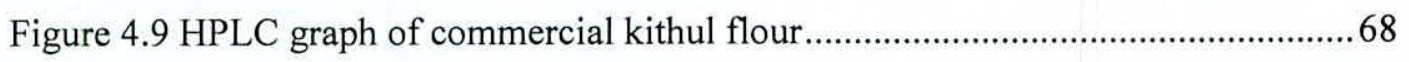

Figure 4.10 HPLC graph of developed product ......................................................69 


\section{ACKNOWLEDGEMENT}

First and foremost I wish to express my sincere gratitude to my internal supervisor Dr. R.A.U.J. Marapana, Department of Food science and Technology, University of Sri Jayewardenepura for his valuable guidance, support and precious advice.

Then I wish to express my sincere thanks to my external supervisor Dr. P. Ranasinghe, Senior Deputy Director, Industrial Technology Institute (ITI) for his valuable advice, continuous encouragement and supervision and also would like to thank for giving me the opportunity to carry out my research at ITI.

It is a pleasure to convey my sincere thanks to all the staff members of ITI for their kind support.

My special thanks to the academic and non-academic staff members of the Department of Food Science and Technology, University of Sri Jayewardenepura for their valuable contribution and advice.

Finally my heartfelt thanks to my loving parents, my husband and my dear friend for their invaluable contribution and moral support throughout my research. 
ABBREVIATIONS

PB Phosphate Buffer

TPC Total Polyphenolic Content

FRAP Ferric Reducing Antioxidant Power

ORAC Oxygen Radical Absorbance Capacity

DNS Dinitro salysilic acid

HPLC High performance liquid chromatography

CP Cinnamon Polyphenols.

UV Ultra Violet.

AC Antioxidant Capacity.

IR Infrared

DSC Differential Scanning Calorimetry.

GCWS granular cold water soluble starch. 


\title{
DEVELOPMENT OF CINNAMON FLAVOURED INSTANT \\ PORRIDGE POWDER USING AMYLASE TREATED KITHUL \\ FLOUR (Caryota urens)
}

Kuhanneya Kugamohan

\begin{abstract}
Traditionally, Kithul flour which is extracted from Caryota urens L. palm has been used in variety of health foods including Kithul gel and thick porridge. However, as yet there is no significant improvement in these traditional products in order to suit modern consumer preferences. Therefore, this study was focused to develop a ready to serve porridge powder with low gelatinization and improved bioactive properties using enzyme hydrolyzed Kithul flour.
\end{abstract}

Kithul flour purchased from market was used for this study and different concentrations of heat resistant alpha amylase were used for hydrolysis of kithul flour. After digestion, maltose content was evaluated using ditro-salicylic acid method. Then samples were tested for gelatinization. Hydrolyzed samples with low gelatinization were selected for the development of less viscous porridge. The porridge samples were prepared after number of primary experiments with different flour:amylase:cinnamon extract ratios as $100 \mathrm{~g}: 0.1 \mathrm{~g}: 0.1 \mathrm{ml}, \quad 150 \mathrm{~g}: 0.1 \mathrm{~g}: 1 \mathrm{ml}$ and $100 \mathrm{~g}: 10 \mathrm{~g}: 0.5 \mathrm{ml}$. Sensory evaluation was conducted for 30 untrained panelists. The results were analyzed using computer aided MINITAB 17.2.1 statistical analysis package according to Kruskal Wallis test at $95 \%$ level of significance. The best sample with $100 \mathrm{~g}: 10 \mathrm{~g}: 0.5 \mathrm{ml}$ flour: amylase: cinnamon extract ratio was selected from the analysis. Total Polyphenolic content and Total 
Antioxidant content assay was carried out for the commercial flour and the developed product.

Total Antioxidant content of the developed product was not significantly different from the commercial kithul flour. Proximate analysis was carried out for the commercial kithul flour and the developed product where the Ash content, crude fiber content, protein content of commercial flour and cinnamon flavoured instant Kithul porridge powder was $(0.3 \%, 0.3 \%),(0.7 \%, 0.6 \%),(0.8 \%, 0.9 \%)$ respectively. The Moisture content of the commercial flour was $14.2 \%$ and for the product was $6.4 \%$, and the Fat content of the commercial flour was $0.12 \%$ and for the product was $0.2 \%$ and the carbohydrate content of the commercial kithul flour was $84.7 \%$ and for the product was $92.2 \%$.

The developed porridge is a potential alternative for traditional product with attractive properties including less thickness, sweetness without added sugar, easy to prepare and enhanced bioactive properties due to incorporation of herbal extract like cinnamon. 